\title{
KEGIATAN BERBAGI PENGETAHUAN SEBAGAI UPAYA PENINGKATAN KOMPETENSI GURU DI SMKN 4 BANDUNG
}

\author{
Muhtada Khoyrudin*), Neneng Komariah**), Edwin Rizal***) \\ Universitas Padjadjaran, Bandung, Indonesia \\ email: E-mail: mumuh017@gmail.com*), neneng.komariah@unpad.ac.id**), \\ edwin.rizal@unpad.ac.id***)
}

Naskah diterima: 08 Januari 2020; direvisi: 25 Januari 2020; disetujui: 28 Januari 2020

\begin{abstract}
Abstrak
Penelitian ini bertujuan untuk mengetahui kegiatan berbagi pengetahuan pada kalangan guru di SMK Negeri 4 Bandung yang meliputi proses berbagi pengetahuan, perilaku guru dalam kegiatan berbagi pengetahuan,dan kendala yang ada dalam kegiatan berbagi pengetahuan. Metode yang digunakan adalah kualitatif dengan pendekatan studi kasus. Teknik pengumpulan data menggunakan observasi, wawancara dan studi kepustakaan. Teknik analisis data meliputi reduksi data, penyajian data dan penarikan kesimpulan. Hasil penelitian menunjukkan bahwa proses kegiatan berbagi pengetahuan terdiri dari kegiatan formal dan non-formal, perilaku guru dalam kegiatan berbagi pengetahuan bergantung kepada kepribadian masing-masing, yaitu ada yang aktif dan ada yang pasif, kendala yang dihadapi adalah belum ada keselarasan antara waktu pelaksanaan berbagi pengetahuan secara formal dengan waktu mengajar, sikap guru yang pasif dalam forum berbagi pengetahuan yang formal, dan kurangnya dana. Kesimpulan kegiatan berbagi pengetahuan di kalangan guru SMK Negeri 4 Bandung sangat penting untuk dilakukan agar dapat meningkatkan pengetahuan dan kompetensi para guru dan sebagai media untuk membangun kebersamaan.
\end{abstract}

Kata kunci: berbagi pengetahuan, guru, SMKN 4 Bandung

\begin{abstract}
The aims of this study is describes the best practices in providing access to e-book in the JAIN This study aims to determine the knowledge sharing activities among teachers at SMK Negeri 4 Bandung which includes the process of sharing knowledge, teacher behavior in knowledge sharing activities, and obstacles faced in knowledge sharing activities. The method used is qualitative with a case study approach. Data collection techniques used observation, interviews and literature study. Data analysis techniques include data reduction, data presentation and conclusion drawing. The results showed that the process of knowledge sharing activities consisted of formal and non-formal activities, the behavior of teachers in sharing knowledge depends on their personalities, there are active and passive ones, the constraints faced are there is no harmony between the time of formal knowledge sharing activities with teaching time, passive teacher attitudes in formal knowledge sharing forums, and lack of funds. The conclusion of knowledge sharing activities among teachers of SMK Negeri 4 Bandung is very important to do in order to improve the knowledge and competencies of teachers and as a medium for building togetherness.
\end{abstract}

Keyword: knowledge sharing, teacher, SMKN 4 Bandung 


\section{PENDAHULUAN}

Knowledge Management (manajemen pengetahuan) adalah metode pengelolaan pengetahuan yang dapat meningkatkan kualitas sumber daya manusia (SDM) organisasi, dengan mengoptimasi jalur komunikasi pengetahuan antar elemennya, sehingga pengetahuan SDM meningkat. Inti dari keberhasilan penerapan manajemen pengetahuan adalah berbagi pengetahuan (knowledge sharing). Berbagi pengetahuan baik yang bersifat spontan, terstruktur maupun tidak terstruktur merupakan hal yang sangat vital bagi keberhasilan perusahaan.

Menurut David Gurteen dalam (Yusup, 2012: 36-37) knowledge sharing atau berbagi pengetahuan adalah suatu konsep yang menggambarkan kondisi interaksi antar orang, bisa dua orang atau lebih, dalam bentuk proses komunikasi yang bertujuan untuk peningkatan dan pengembangan diri setiap anggotanya. Berbagi pengetahuan hanya dapat dilakukan apabila setiap anggota organisasi memiliki kesempatan yang luas dalam menyampaikan pendapat, ide, kritikan dan komentarnya kepada kolega lainnya. Berbagi pengetahuan melibatkan pemindahan pengetahuan dari satu orang ke seseorang lainnya serta sering kali menjadi perhatian utama dalam Knowledge Management dan banyak dibicarakan dalam literatur. Selanjutnya organisasi harus mendokumentasikan hasil pemikiran atau pengetahuan baru sebagai luaran dari berbagi pengetahuan tersebut dan siap untuk mengimplementasikan metode-metode yang berbeda untuk membagikan jenis-jenis pengetahuan yang berbeda.

Konsep manajemen pengetahuan bermula dan berkembang di dunia bisnis dengan tujuan untuk meningkatkan kinerja perusahaan dalam memperoleh kuntungan. Manajemen pengetahuan digunakan untuk memperbaiki komunikasi diantara manajemen dan diantara pekerja, menanamkan budaya berbagi pengetahuan, dan mempromosikan sistem penghargaan berbasis kinerja. (Almah, 2013).

Idealnya organisasi pendidikan seperti sekolah memfasilitasi proses pendidikan non formal para guru melalui penerapan manajemen pengetahuan di sekolah yang bersangkutan. Manajemen pengetahuan bagi guru merupakan proses yang terus menerus untuk memperoleh, menyimpan, berbagi, mengerahkan, dan berinovasi pengetahuan untuk mengajar (Feng, J., Zhang, J., Mu, Y., Sui, Z., \& Tang, 2012). Pengetahuan didapatkan dari berbagai cara seperti melalui proses komunikasi personal, interpersonal, kelompok diskusi, maupun melalui proses belajar atau pengamatan dan pengalaman sendiri. Pengetahuan selalu tumbuh dan berkembang, oleh karena itu bagi organisasi yang menyadari bahwa pengetahuan itu penting, maka mereka akan mengelola pengetahuan tersebut sebaik mungkin.

Menurut Undang-undang No. 2 Tahun 1989 tentang Pendidikan Nasional, sekolah adalah satuan pendidikan yang berjenjang dan berkesinambungan untuk menyelenggarakan kegiatan belajar mengajar. Sedangkan menurut Daryanto (2013) sekolah adalah bangunan atau lembaga untuk belajar serta tempat menerima dan memberi pelajaran. Jadi sekolah berperan sebagai tempat berlangsungnya proses pendidikan serta proses mengajar, sehingga pelaku utama dalam proses pendidikan di sekolah adalah guru sebagai pendidik dan siswa sebagai peserta didik. Disamping itu terdapat komponen lain yang terlibat dalam pengelolaan sekolah, seperti kepala sekolah, tenaga kependidikan, dll.

Guru memiliki posisi yang strategis dalam proses pendidikan, karena dia merupakan pelaku utama dalam pengelolaan proses belajar. Meskipun sekarang dikembangkan metode pembelajaran yang berorientasi pada kompetensi siswa (student based learning), namun guru harus tetap cerdas dan aktif serta berusaha untuk mewujudkan suasana belajar dan proses pembelajaran yang aktif, menciptakan peserta didik yang konsisten dalam mengembangkan ilmu pengetahuan serta terampil dalam mendidik maupun terampil dalam pekerjaan sesuai dengan bidang keahliannya. Oleh karena itu, dalam organisasi sekolah belajar itu tidak hanya penting bagi peserta didik, melainkan juga bagi semua elemen yang terlibat dalam sekolah terutama guru dan kepala sekolah. 
Menurut Undang-Undang Republika Indonesia No 14 Tahun 2005 Tentang Guru dan Dosen Pasal 1 ayat (1), Guru adalah pendidik profesional dengan tugas utama mendidik, mengajar, membimbing, mengarahkan, melatih, menilai, dan mengevaluasi peserta didik pada pendidikan anak usia dini jalur pendidikan formal, pendidikan dasar, dan pendidikan menengah. Dilihat dari kedudukan, fungsi dan tujuannya berdasarkan pasal 2 Undang-Undang Republika No 14 Tahun 2005 dimana pasal tersebut menjelaskan tentang: (1) Guru mempunyai kedudukan sebagai tenaga profesional pada jenjang pendidikan dasar, pendidikan menengah, dan pendidikan anak usia dini pada jalur pendidikan formal yang diangkat sesuai dengan peraturan perundang-undangan, (2) Pengakuan kedudukan guru sebagai tenaga profesional sebagaimana dimaksud pada ayat 1 dibuktikan dengan sertifikat pendidik.

Peran penting guru dalam proses belajar di sekolah harus didukung oleh keahlian dan pengetahuan yang selalu relevan dan aktual dari para guru yang bersangkutan. Oleh karena itu para guru harus selalu meningkatkan keahlian dan pengetahuannya baik melalui jalur pendidikan formal, maupun secara non formal, misalnya dengan mengikuti pelatihan, mengikuti seminar, belajar mandiri dengan mengakses berbagai sumber informasi, dan berdiskusi untuk berbagi pengetahuan dengan sesama rekan guru

Dalam proses pendidikan di sekolah, baik guru maupun murid sangat tergantung kepada penyebaran, pengelolaan, pengumpulan dan pengorganisasian pengetahuan secara tepat. Oleh karena itu perlu dilakukan kegiatan berbagi pengetahuan agar semua kegiatan operasional sekolah dapat berjalan dengan baik dan agar pengetahuan atau informasi dapat disebarkan dan diserap dengan tepat. Melalui proses berbagi pengetahuan maka potensi diri para guru dapat dikembangkan secara optimal dan bermanfaat bagi peserta didik, masyarakat, bangsa, dan negara, sehingga mutu sekolah dapat diakui masyarakat.

Melalui penerapan manajemen pengetahuan di sekolah, maka diharapkan tersedia pengetahuan yang terdistribusikan ke seluruh organisasi sekolah sehingga orangorang yang ada dalam organisasi sekolah tersebut dapat menggunakannnya untuk mengembangkan potensi dirinya dalam rangka mencapai kemajuan organisasi. Jadi salah satu cara untuk meningkatkan kinerja guru yaitu dengan mengembangkan knowledge management serta kemampuan individu yang dimiliki oleh para guru. Berbagi pengetahuan merupakan salah satu langkah penting dalam knowledge management.

SMKN 4 Bandung merupakan salah satu sekolah menengah kejuruan yang berada di Kota Bandung. Sekolah Menengah Kejuruan (SMK) merupakan salah satu bentuk satuan pendidikan formal yang menyelenggarakan pendidikan kejuruan dengan berbagai program keahlian. Program keahlian yang dilaksanakan di SMK menyesuaikan dengan kebutuhan dunia kerja yang ada. Pendidikan kejuruan adalah pendidikan menengah yang menyiapkan peserta didik agar siap bekerja dalam bidang tertentu.

SMKN 4 Bandung merupakan sekolah menengah kejuruan yang memiliki kelompok bidang keahlian Ketenaga Listrikan, Audio Video, dan Teknik Komputer dan Informatika. Di sekolah tersebut telah dilaksanakan kegiatan diskusi diantara guru sebagai upaya berbagi pengetahuan dan pengalaman di antara para guru. Oleh karena itu menarik untuk diketahui bagaimana proses berbagi pengetahuan tersebut dilaksanakan. Secara spesifik tujuan penelitian adalah untuk mengetahui proses berbagi pengetahuan yang dilaksanakan di SMKN 4 Bandung, perilaku guru dalam proses berbagi pengetahuan di SMKN 4 Bandung, kendala-kendala yang dihadapi dalam pelaksanaan kegiatan berbagi pengetahuan di SMKN 4 Bandung.

\section{METODE}

Penelitian ini menggunakan metode kulitatif dengan pendekatan studi kasus. Metode penelitian kualitiatif menurut Sugiyono (2013) sering disebut sebagai metode penelitian naturalistik karena penelitiannya dilakukan pada kondisi yang alamiah (natural setting). Penelitian kualitatif merupakan metode yang berlandaskan 
postpositivisme, yaitu digunakan untuk meneliti kondisi objek yang ilmiah. Objek yang ilmiah adalah objek yang berkembang apa adanya, tidak dimanipulasi oleh peneliti dan kehadiran peneliti tidak memengaruhi dinamika pada objek tersebut. Pendekatan studi kasus digunakan untuk melihat realitas dari perspektif unit analisis. Unit analisis dari penelitian ini adalah manusia sebagai pelaku dan penggerak dari sebuah organisasi.

Pendekatan studi kasus dalam penelitian ini digunakan agar dapat mengkaji lebih mendalam dan rinci ke dalam konteks penelitian. Menurut Yin (2013) studi kasus merupakan strategi yang cocok bila pokok pertanyaan suatu penelitian berkenaan dengan how atau why, dan bilamana fokus penelitiannya terletak pada fenomena. Dalam penelitian ini fenomena yang diteliti adalah kegiatan berbagi pengetahuan di kalangan guru di SMKN 4 Bandung.

Teknik pengumpulan data menggunakan wawancara, observasi, dan studi pustaka. Wawancara dilakukan pada beberapa informan yang ditentukan dengan teknik purposive sampling, yaitu memilih informan dengan pertimbangan dan tujuan tertentu. Hasil penelitian tidak akan digeneralisasikan, karena pengambilan subjek tidak secara random. Hasil penelitian dengan metode kualitatif ini hanya berlaku untuk kasus situasi sosial tertentu, misalnya orang tersebut yang dianggap paling tahu tentang apa yang kita harapkan, atau mungkin dia sebagai penguasa sehingga akan memudahkan peneliti menjelajahi obyek/situasi sosial yang diteliti. (Sugiyono,2013). Subjek penelitian merupakan orang-orang yang dianggap mampu memberikan informasi mengenai latar belakang dan keadaan yang sebenarnya dari obyek yang diteliti sehingga data yang dihasilkan dapat akurat. Kriteria yang dipilih menjadi informan utama dalam penelitian antara lain, (1) Merupakan pencetus/anggota dari kegiatan berbagi pengetahuan, (2) Guru tetap di SMKN 4 Bandung, (3) Selalu mengikuti kegiatan berbagi pengetahuan, (4) Mampu menggambarkan kembali pengalaman yang dialaminya. Terdapat 4 orang yang memenuhi kriteria tersebut yaitu Bapak Y.K, Bapak T.S, Bapak A.W.P., dan Bapak A.M. Teknik analisis data meliputi reduksi data, penyajian dan analisis data, dan penarikan kesimpulan.
Objek penelitian adalah kegiatan berbagi pengetahuan di kalangan guru SMKN 4 Bandung. Tujuan penelitian yaitu untuk mengetahui proses berbagi pengetahuan yang dilakukan oleh guru, untuk mengetahui perilaku guru dalam proses berbagi pengetahuan, dan untuk mengetahui kendala yang dihadapi dalam kegiatan berbagi pengetahuan di SMKN 4 Bandung.

\section{PEMBAHASAN}

\section{Proses Berbagi Pengetahuan}

Kegiatan "berbagi pengetahuan adalah suatu konsep yang menggambarkan kondisi interaksi antar orang, bisa dua orang atau lebih, dalam bentuk proses komunikasi yang bertujuan untuk peningkatan dan pengembangan diri setiap anggotanya." (Yusup, 2012). Sebagai contoh, seseorang menyampaikan ide-ide kreatifnya pada suatu kegiatan diskusi ilmiah di dalam kelas, dan di pihak lain orang-orang mendengarkan dengan seksama, menerima gagasan-gagasan orang tersebut untuk kemudian disimpan dalam memori sebagai hasil belajar. Setiap anggota dalam forum diskusi tadi bisa saling memberi dan menerima informasi dan pengetahuan dari anggota lainnya.

Gambar 1.

\section{Proses Kegiatan Berbagi Pengetahuan}

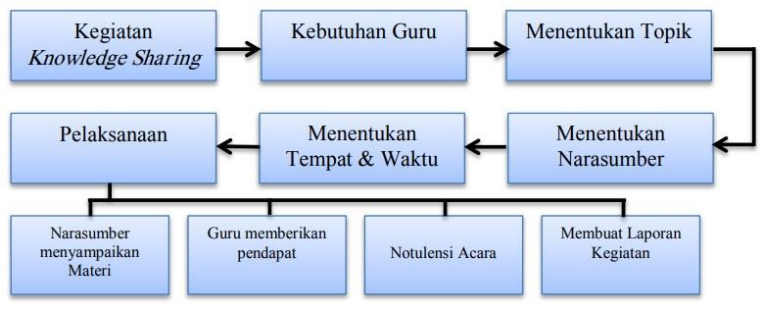

Awal terciptanya kegiatan berbagi pengetahuan pada dasarnya karena adanya kebutuhan yang dimiliki oleh suatu organisasi dalam hal ini sekolah, yang terus menerus ingin maju dan berkembang serta meningkatkan kemampuan dari anggotanya dalam hal ini guru. Di SMKN 4 Bandung kegiatan berbagi pengetahuan berawal dari kebutuhan, karena pada dasarnya pengetahuan guru itu bervariasi 
ada yang lebih paham, ada yang belum. Pada awalnya guru-guru di SMKN 4 Bandung lebih mengenal kegiatan-kegiatan ini sebagai FGD (Forum Grup Diskusi) yang di dalamnya sering memunculkan pengetahuan-pengetahuan baru bagi guru. Dengan adanya kegiatan berbagi pengetahuan akan tumbuh pengetahuan yang baru, yang dihasilkan dari perpaduan pengetahuan-pengetahuan yang ada. Oleh sebab itulah kegiatan berbagi pengetahuan di SMKN 4 Bandung berperan untuk menutupi kekurangan-kekurangan yang ada dari setiap gurunya.

Proses pelaksanaan kegiatan berbagi pengetahuan di SMKN 4 Bandung bisa dibagi dalam dua kategori, yaitu kegiatan yang formal, dan kegiatan yang non-formal. Dalam kegiatan formal guru-guru akan mentransfer pengetahuannya pada sebuah acara dengan topik pembahasan yang sudah disesuaikan dengan kebutuhan yang ada. Contohnya pada setiap mata pelajaran di kegiatan MGMP (Musyawarah Guru Mata Pelajaran). Dalam kegiatan ini hanya dihadiri oleh guru-guru dalam satu kelompok mata pelajaran yang sama. Sebagai contoh dalam mata pelajaran kejuruan yaitu mata pelajaran gambar teknik. Akan dicari diantara anggota dari guru-guru tersebut, guru mana yang menguasai mengenai gambar teknik dan dia akan ditunjuk sebagai pembicara. Apabila diperlukan akan mengundang dari pihak industri untuk hadir ke sekolah untuk menjelaskan tentang mata pelajaran gambar teknik. Jadi untuk narasumber bisa guru dari SMKN 4 sendiri, atau mengundang dari pihak luar (industri) sebagai guru tamu. Melalui kegiatan seperti ini, narasumber yang membagikan pengetahuan dan pengalamannya kepada audiens juga bisa mendapatkan pengetahuan yang baru, karena pada kegiatan ini terjadi komunikasi dua arah dimana narasumber dan audiens akan saling bertukar pengetahuan dan pengelamannya, sehingga baik narasumber ataupun audiens sama-sama akan mendapatkan pengetahuan yang baru. Hasil kegiatan berbagi pengetahuan ini, akan dibuat sebuah dokumen notulensi atau laporan tertulis yang dibukukan yang akan digunakan sebagai bahan evaluasi kedepannya. Menurut Komariah (2019) dokumen hasil berbagi pengetahuan diantara guru-guru dapat disimpan di perpustakaan sekolah yang akan menjadi sumber referensi bagi para guru, dan merupakan koleksi local content yang akan memperkaya koleksi perpustakaan sekolah.

Kegiatan berbagi pengetahuan juga bisa berlangsung di luar sekolah. Sebagai contoh guru mengikuti pelatihan, seminar atau workshop yang diselenggarakan oleh industri atau oleh institusi pendidikan lain. Selanjutnya guru yang telah mengikuti kegiatan tersebut akan berbagi pengetahuannya kepada rekanrekannya di SMKN 4 Bandung.

Adapun proses kegiatan berbagi pengetahuan secara non-formal dimulai ketika guru-guru di SMKN 4 Bandung yang merasa butuh pengetahuan dan akan menanyakan pada rekan guru yang mungkin lebih senior dan berpengalaman, atau guru yang baru mengikuti pelatihan atau workshop, sehingga bisa mendapatkan pengetahuan baru. Kegiatan ini bisa dilakukan kapan saja. Bisa sambil mengobrol ketika sedang istirahat, atau mungkin menggunakan media sosial seperti whatsapp dan media sosial lainnya. Proses berbagi pengetahuan secara non-formal juga dilaksanakan oleh beberapa guru yang sudah mengikuti pelatihan-pelatihan dari luar sekolah dan kemudian membagikan kembali pengetahuannya kepada rekannya ketika sudah kembali ke sekolah. Sebagai contoh apabila ada alat baru yang dimiliki dan beberapa orang sudah menguasai alat tersebut, maka guru yang lain akan menanyakan bagaimana cara mengoperasikan alat tersebut.

Untuk mengontrol kegiatan berbagi pengetahuan, maka topik yang akan dibahas biasanya diagendakan terlebih dahulu dan disesuaikan dengan kebutuhan yang ada pada saat itu, sehingga materi yang disampaikan atau dibahas lebih fokus. Materi yang akan dibahas bisa diajukan oleh guru yang membutuhkan pengetahuan tentang topik tersebut. Kadang-kadang dilakukan kegiatan berbagi pengetahuan mengenai topik yang sedang aktual atau banyak dibicarakan dalam masyarakat dengan tujuan untuk meningkatkan wawasan guru tentang isu-isu sosial yang sedang berkembang di masyarakat. Hal ini sangat penting agar para guru bisa menyikapi dengan tepat mengenai berbagai 
informasi hoax yang beredar di masyarakat. (Komariah, 2019).

Dari kegiatan berbagi pengetahuan yang selama ini telah dilakukan, para guru tentunya mendapatkan pengalaman-pengalaman berharga. Mereka akan merasa bertambah ilmu pengetahuannya, keterampilannya, dan dapat melengkapi ketidaktahuan yang sebelumnya ada pada diri mereka. Pada dasarnya mereka dapat menambah wawasan dan kompetensi melalui kegiatan saling berbagi pengetahuannya, dan saling bertukar informasi.

Proses berbagi pengetahuan yang terjadi di SMKN 4 Bandung, sejalan dengan SECI Model yang dirumuskan oleh Nonaka dan Takeuchi (1995) yang menjelaskan siklus dalam manajemen pengetahuan yang terdiri dari socialization, externalization, combination, internalization. (Adiprabowo, 2019). Socialization merupakan proses transfer informasi diantara orang-orang berupa percakapan. Dalam hal ini diantara guru terjadi transfer informasi, baik melalui diskusi kelompok ataupun melalui percakapan antar pribadi. Externalization yaitu proses transfer dari tacit knowledge (pengetahuan atau ide yang masih dalam pemikiran seseorang) ke explicit knowledge (pengetahuan yang sudah dikomunikasikan). Dalam hal ini, para guru menyampaikan pemikiran atau ide-ide baru dalam proses berbagi pengetahuan yang dilaksanakan baik ketika diskusi kelompok maupun ketika berkomunikasi antar pribadi. Selanjutnya tahap combination yang merupakan transfer explisit knowledge ke explisit knowledge. Dalam proses berbagi pengetahuan ini, ada tim yang ditunjuk untuk mencatat semua informasi yang disampaikan dan didiskusikan, sehingga di akhir pertemuan ada dokumen yang dihasilkan yang selanjutnya akan disimpan dan menjadi referensi bagi para guru. Tahap akhir merupakan internalization, merupakan transfer informasi dari explicit knowledge ke tacit knowledge. Dalam hal ini, setelah proses berbagi pengetahuan selesai maka para guru merenungkan kembali informasi yang telah mereka terima dan selanjutnya akan memunculkan ide-ide atau pemikiran baru, dimana hal ini merupakan tacit knowledge yang selanjutnya akan di komunikasikan (socialization) dan seterusnya.

$$
\begin{array}{rrr}
\text { Dengan demikian melalui kegiatan } \\
\text { berbagi pengetahuan maka proses }
\end{array}
$$
socialization, externalization, combination dan internalization akan terus berulang menjadi siklus yang tidak pernah terputus, sehingga pengetahuan akan terus berkembang. Melalui proses tersebut maka knowledge management di suatu institusi dapat dilaksanakan secara efektif.

\section{Perilaku Guru Dalam Kegiatan Berbagi Pengetahuan}

Guru-guru di SMKN 4 Bandung sangat antusias dengan adanya kegiatan berbagi pengetahuan. Berdasarkan observasi lapangan mereka nampak sangat bersungguh-sungguh ketika sedang mengikuti kegiatan berbagi pengetahuan, karena bagaimana pun juga guru harus mengetahui tentang tuntutan-tuntutan pekerjaan yang harus mereka lakukan. Walaupun mereka tahu bahwa narasumber dari kegiatan berbagi pengetahuan ini merupakan rekan sejawatnya, namun mereka menganggap kegiatan ini sanggat penting sebagai salah satu upaya untuk meningkatkan pengetahuan dan kompetensi agar bisa memenuhi tuntutan pekerjaan. Hal ini sangat penting "karena pada dasarnya diharapkan masing-masing guru memiliki sikap yang berbeda, dengan tuntutan metode pembelajaran dari kurikulum 2013, metode pembelajaran di sekolah atau di kelas sekarang menggunakan metode student center yang mana seluruh pembelajaran saat ini berpusat pada siswa, tidak seperti dulu yang menggunakan metode pembelajaran teacher center, dulu guru yang selalu berbicara di depan kelas untuk menerangkan, nah saat ini sangatlah di dorong menggunakan metode pembelajaran student center pembelajaran berpusat di siswa dengan pendekatan saintifik dengan pendekatan 5M (Mengamati, Menanya, Mencoba, Menalar, dan Mengkomunikasikan)." (Bapak YK, wawancara, September, 2018).

Pada umumnya setiap guru dalam melakukan kegiatan berbagi pengetahuan sangat terbuka. Guru yang memiliki pengetahuan dan pengalaman yang luas akan menyampaikan dan menjelaskan pengetahuan 
dan pengalamannya pada rekan-rekan guru yang relatif membutuhkan. Perilaku guru dalam proses berbagi pengetahuan sangat dipengaruhi oleh kepribadian masing-masing guru. Terdapat guru-guru yang selalu bersemangat untuk mencari pengetahuan baru melalui bertanya dan berdiskusi dengan rekan-rekannya, ada yang hanya ikut mendengarkan, dan adapula mereka yang pasif. Demikian pula halnya dalam proses berbagi pengetahuan ketika seorang guru menjadi narasumber. Ada yang dapat menyampaikan ilmu pengetahuan dan pengalaman yang dia miliki kepada rekannya dengan baik, dan ada pula yang kurang bersemangat.

Selanjutnya kegiatan berbagi pengetahuan di SMKN 4 Bandung bisa bisa dilakukan tidak hanya melalui tatap muka langsung baik secara formal maupun non formal, tetapi bisa juga dilakukan melalui media smartphone berupa diskusi melalui media sosial. Para guru sudah memiliki media sosial whatsapp dan face book. Mereka bisa menggunakan media sosial ini untuk berbagi pengetahuan, kapan saja dan dimana saja tanpa terikat ruang dan waktu. Disamping itu, berdasarkan observasi di perpustakaan sekolah SMKN 4 Bandung, terdapat karya ilmiah yang ditulis oleh guruguru, sehingga guru-guru yang lainnya dapat membaca dan mempelajarinya.

Dengan demikian proses berbagi pengetahuan bisa dilakukan secara tatap muka, dan melalui media elektronik dan media cetak.

\section{Kendala Dalam Kegiatan Berbagi Pengetahuan}

Terdapat beberapa kendala yang dihadapi dalam kegiatan berbagi pengetahuan di SMKN 4 Bandung. Adapun kendala-kendala yang terjadi antara lain sebagai berikut:

Pertama, kendala yang berkaitan dengan waktu pelaksanaan berbagi pengetahuan. Tidak setiap kegiatan berbagi pengetahuan bisa dihadiri oleh seluruh guru SMKN 4, karena sering terjadi pada saat kegiatan berbagi pengetahuan ada beberapa guru yang harus masuk kelas untuk mengajar. Sebagai contoh pada kegiatan Whorshop Teaching Factory yang mana peserta dari kegiatan ini adalah seluruh guru di SMK Negeri 4 Bandung dengan jumlah kurang lebih 112 orang guru. Namun pada acara tersebut, berdasarkan observasi peneliti hanya sekitar $85 \%$ guru yang mengikuti kegiatan, karena kegiatan tersebut bertepatan dengan waktu kegiatan belajar mengajar dan ada sebagian guru yang lebih memilih mengajar di kelas.

Kedua, kendala yang berasal dari sikap guru selama kegiatan berbagi pengetahuan berlangsung. Tidak semua guru angkat bicara dalam proses berbagi pengetahuan yang bersifat formal. Hanya beberapa orang saja yang memberikan masukan, bertanya, atau menceriterakan pengalamannya. Padahal idealnya forum formal tersebut bisa menjadi wahana guru untuk mengaktualisasikan dirinya.

Ketiga, kendala yang berkaitan dengan masalah dana untuk menyelenggarakan kegiatan berbagi pengetahuan secara formal. Untuk kegiatan yang diselenggarakan di lingkungan sekolah, maka dana disediakan oleh pihak sekolah. Oleh karena itu frekuensi kegiatan berbagi pengetahuan secara formal relatif rendah. SMKN 4 Bandung mampu menyelenggarakan inhouse training di awal tahun ajaran baru, padahal perkembangan teknologi yang begitu cepat mengharuskan guru untuk sering mengikuti pelatihan agar mereka mampu mengajar dengan optimal. Adakalanya guru harus mengeluarkan uang sendiri agar bisa mengikuti workshop yang diselenggarakan di luar sekolah.

Namun berbagai kendala tersebut dapat diatasi melalui kegiatan berbagi pengetahuan secara non-formal. Kegiatan tersebut relatif tidak membutuhkan dana dan berlangsung dalam suasana yang santai sehingga para guru yang bergabung semuanya akan berbicara dengan aktif dan lebih terbuka, baik untuk berbagi pengalaman maupun untuk menyampaikan keluhan. Kegiatan berbagi pengetahuan secara non-formal juga waktunya bisa diatur disesuaikan dengan waktu luang para guru, sehingga tidak akan bentrok dengan waktu mengajar.

\section{SIMPULAN}

Proses berbagi pengetahuan di SMK Negeri 4 Bandung berawal dari kebutuhan 
guru yang harus selalu meningkatkan pengetahuan dan kompetensinya, agar mereka mampu menjadi pendidik yang profesional. Baik kegiatan berbagi pengetahuan secara formal maupun secara non-formal sangat bermanfaat bagi para guru. Manfaat yang dirasakan tidak hanya peningkatan pengetahuan dan kompetensi, tetapi juga bisa membangun kebersamaan dan semangat untuk berbagi.

Perilaku guru dalam kegiatan berbagi pengetahuan sangat dipengaruhi oleh kepribadian masing-masing. Mereka yang berkepribadian terbuka akan mengekspresikan dirinya dengan semangat, baik dalam kegiatan berbagi pengetahuan yang formal maupun yang non-formal. Namun mereka yang cenderung pasif, menjadi lebih aktif dalam forum berbagi pengetahuan secara non-formal. Oleh karena itu forum non-formal harus selalu dikembangkan agar bisa menjadi wadah bagi semua guru untuk berbagi pengetahuan.

Kendala yang dihadapi dalam kegiatan berbagi pengetahuan di SMKN 4 Bandung adalah masalah waktu kegiatan yang sering bersamaan dengan waktu mengajar, masalah sikap guru yang pasif dalam kegiatan berbagi pengetahuan yang formal, dan dana yang belum ada bantuan dari pemerintah. Untuk mengatasi kendala tersebut, maka pihak sekolah harus lebih mengembangkan forum berbagi pengetahuan secara non-formal, dan mengundang pihak industri untuk menyelenggarakan berbagai pelatihan, workshop, dll di sekolah.

\section{DAFTAR PUSTAKA}

Adiprabowo, H.N., Yusup, P.M., Anwar, R. K. (2019). Berbagi pengetahuan sebagai pembelajaran organisasi di Perpustakaan Nasional Republik Indonesia. Jurnal Kajian Informasi \& Perpustakaan, 7(2).
Almah H. (2013). Membangun Inovasi Perpustakaan Perguruan tinggi Melalui Konsep Knowledge Management. Khizanah Al Hikmah, 1(2).

Daryanto, Farid, M. (2013). Konsep Dasar Manajemen Pendidikan Sekolah. Gava Media.

Feng, J., Zhang, J., Mu, Y., Sui, Z., Tang, H. (2012). Research on Teacher's Knowledge Management. International Conference on Innovation and Information Management. Research on Teacher's Knowledge Management. International Conference on Innovation and Information Management, 36, 303-306.

Komariah, N. (2020). Knowledge Sharing Sebagai Komunikasi Organisasi Sekolah Di Era Post-Truth. Komunikasi Organisasi Dalam Era Post-Modern, 17-24.

Sugiyono. (2013). Metode Penelitian Kombinasi (Mixed Methods). Alfabeta.

Undang-Undang Republik Indonesia No 14 Tahun 2005 Tentang Guru dan Dosen. (2005). Dipetik September 11, 2018, dari http://sumberdaya.ristekdikti.go.id/wpcontent/uploads/2016/02/uu-nomor-14tahun-2005-ttg-guru-dan-dosen.pdf

Yin, R. K. (2013). Studi Kasus: Desain \& Metode. Rajawali Pers.

Yusup, P. M. (2012). Perspektif Manajemen Pengetahuan Informasi, Komunikasi, Pendidikan, dan Perpustakaan. Rajawali Pers. 